\title{
WELFARE AND LEGAL ASPECTS OF MAKING DECISIONS ON MEDICAL TREATMENTS OF PET ANIMALS
}

\begin{abstract}
When it comes to humans and the necessity for their young ones' medical treatments, the parental responsibility is crucial. The decisions made by parents involve the legal aspects as well as welfare aspects, respectively. Pet animals are usually classified as property in the European Union, but pets are the same as kids regarding medical treatments and illnesses or diseases. In that case, the decisions are made by their owners, posing a legal challenge only if the proposed treatment can trigger damage or needless pain, as defined by the Law on pet animals' welfare. In this article, there will be discussed the best interests both in legal and welfare aspects of decisions being made in the medical treatments of the pets by their owners. Reaching the choice of pets' medical treatments will primarily be focused on pets protection and welfare avoiding unnecessary pain, which is in the pets ' best overall welfare interests. While the statute law is not a mandatory one considering the pets' best interests, this article might be a useful resource for professional veterinarians and practitioners. At the same time, this article regards of the best interests of the pets and it can be integrated into the existing ethical frameworks for making medical decisions and more humane treatment of pet animals.
\end{abstract}

Keywords: legal aspects, veterinary, pet animals, pets welfare.

\footnotetext{
* Associate Professor, The University of Business Academy in Novi Sad, Serbia, The Faculty of Economics and Engineering Management in Novi Sad, Serbia e-mail: nikola.puvaca@fimek.edu.rs ** Communications Officer, The University of Bern, The Swiss 3R Competence Centre (3RCC), Bern, Switzerland, e-mail: chantal.britt@swiss3rcc.org
} 


\section{Introduction}

Suppose medical treatment is in the patient's best interest, having in mind that that interest aligns with all patient values, and fulfills economically available resources to obtain the treatment, then for such medical treatment. In that case, it is stated to be a lawful one. ${ }^{1}$ Subsequently, for mature patients with the ability to give specific medical treatment permission, the legality of treatment is indisputable. Nevertheless, for patients with no ability, the situation is slightly shrouded by struggles to make choices in their "best interests," when the final term is considered mysterious, discriminatory, and too complicated to decide. ${ }^{2}$

Therefore, mature patients with no ability may not be appropriate as an analogy for pet animal patients. In the viewpoint of the difficulty with uncovering out what pet animals need, predominantly if trusting on human understanding of their standards and favorites, it is more typical to comparability the position of the pet animal patient with that of the newborn kid, whose ideals and choices are not yet acknowledged. ${ }^{3}$ Even though enticingly upfront, this evaluation must integrate a credit that, ultimately, pet animal feelings and requirements will be genuinely interpreted by humans, maybe letting resolve the specific pet animal's preferences concerning their life conditions. Such explanations will also vary on pet animal welfare scientists' emerging experience, respectively. ${ }^{4}$

The distinction in legal status between kids and pet animals needs to be respected, particularly because the pet animals are considered property.

Keeping in mind mentioned, this review aims to describe legal and welfare aspects of reaching choice for the medication of pet animals, compared to human patients, especially young kids, as reference.

\footnotetext{
${ }^{1}$ Back, A., Arnold, R., Baile, W., Tulsky, J., Fryer-Edwards, K. (2005). Approaching Difficult Communication Tasks in Oncology, A Cancer Journal for Clinicians, 55, pp. 164-177.

${ }^{2}$ Branscombe, N. R., Schmitt, M. T., Schiffhauer, K. (2007). Racial Attitudes in Response to Thoughts of White Privilege, European Journal of Social Psychology, 37(2), pp. 203-215.

${ }^{3}$ Brune, K., Renner, B., Tiegs, G. (2014). Acetaminophen/Paracetamol: A History of Errors, Failures and False Decisions, European Journal of Pain, 19(7), pp. 953-965.

${ }^{4}$ Glenk, L. M. (2017). Current Perspectives on Therapy Dog Welfare in Animal-Assisted Interventions, Animals, 7(2), p. 7.
} 


\section{Issues of "Best Interests" Design in the Similarity of Kids and Pet Animals Choice for Medication}

When it comes to kids, the best interests test originated as a legal requirement in kid custody cases at common law and was later applied to pediatric healthcare. ${ }^{5}$ A main unruly with an impartial "best interest" routine is the trouble of crucial "best interests", which may be ontological or epistemological. ${ }^{6}$

Consequently, nowadays, the "gold standard" is applied as a constructive edition of best interests instead of a pessimistic edition where the emphasis is on the evasion of harm. ${ }^{7}$ But "gold standard" must likewise be expanded further than just medical benefits. Nevertheless, the Court of Appeal reversed the ruling in the lower courts, which had found for the medical professionals based on the "unreasonableness" of the mother's refusal to consent in a case where a kid best medical interests where to have a liver transplant procedure according to medical recommendation. ${ }^{8}$ Hence, the "best interests" choice for the kid cannot be founded exclusively on the maintenance of living, implying that addition of lifetime at any cost to the kid welfare is of itself not an explanation for medical intermediation, and can not only be founded exclusively on the evasion of harm. ${ }^{9}$

Setting to the pet animal patient, there is a concern arise that various veterinary choices are founded on precisely two parameters. One of them is extending the life of the pet and the second one is to avoid the pet's harm. The problems arise when other factors are excluded, which should inform a "best interests" choice. Additionally, in pet animals, there is significant discussion over the location of death in these calculations. ${ }^{10}$

\footnotetext{
${ }^{5}$ Gray, C., Fordyce, P. (2020). Legal and Ethical Aspects of 'Best Interests' Decision-Making for Medical Treatment of Companion Animals in the UK, Animals, 10(6), 1009, https://doi. org/10.3390/ani10061009; Puvača, N., de Llanos Frutos, R. (2020). Risk of Antimicrobial Resistance Development from Pet Animals to Humans: Case of Enterobacteriaceae Family, Lupine Online Journal of Pharmacology \& Clinical Research, 2(3), pp. 202-206.

${ }^{6}$ Ramsey, P.L., Khan, S. (2020). Dilemmas, emotion and innovation in tertiary education, Innovations in Education and Teaching International.

${ }^{7}$ Yeates, J. (2010). Death is a Welfare Issue, Journal of Agricultural and Environmental Ethics, 23, pp. 229-241.

${ }^{8}$ Manning, J. (2018). "Fair, Simple, Speedy and Efficient"? Barriers to Access to Justice in the Health and Disability Commissioner's Complaints Process in New Zealand, New Zealand Law Review, 4, pp. 611-656.

${ }^{9}$ Vaughan Brakman, S. (2019). The Principle of Subsidiarity in the Hague Convention on Intercountry Adoption: A Philosophical Analysis, Ethics \& International Affairs, 33(2), pp. 207-230. ${ }^{10}$ Hughes, A. (2017). Understanding the Drivers of Southeast Asian Biodiversity Loss, Ecosphere, $8(1)$, pp. 16-24.
} 
According to some research, ${ }^{11}$ a pet animal's death is not considered to harm a pet animal's welfare. Once the animal brain has stopped working, the pet will have no consciousness of any reactions that might be portrayed as aversive suffering. ${ }^{12}$ Though, some other researchers are not agreeing with fact that suffering is not the only harm that can be triggered to a pet animal, so they stated that mortality of pet animal is likewise theoretically a harm, by stingy the pet animal of the opportunity of experiencing positive mental states if remaining alive. ${ }^{13}$

Deprivation and suffering as well could implicate the harms of a pet animal, respectively. The pain is stated as the most horrible harm that could be imposed on pet animals, owing to the apparent lack of ability of pet animals to foresee the end of their suffering. Therefore, even though death can present the most significant deprivation, it may not be the harshest harm. If life's harmless presence has a positive value to the pet animal, then death is harm, but on the other hand, if that life has a negative value, then death is gain. Termination of life as a choice-making in veterinary medicine highlights the avoidance of suffering, requiring that the decision is made for euthanasia. ${ }^{14}$

The ethical context for choice-making for veterinary patients integrates the suggestion that "short-term harm" for "long-term best" benefits can be defended employing a comparable methodology to support research on animals. In such case, the veterinary surgeon is positioned at the bottom of the procedure, first choosing whether the proposed treatment is in the best interests of the animal, ${ }^{15}$ and that decisions are made using standards such as improved health, improved life quality, reducing the harm and accomplishment a harm-benefit evaluation. ${ }^{16}$

Hence, suggest that grounding choice on designs of "best interests" for kids could lead to a further comprehensive methodology for veterinary treatments, with an effort to exploit a current context, established for kids, to define the contents of a "best interests" debate for a pet animal patients. ${ }^{17}$

\footnotetext{
${ }^{11}$ Yeates, J. (2010), op. cit.

${ }^{12}$ Ziv, G. (2017). The Effects of Using Aversive Training Methods in Dogs-A Review, Journal of Veterinary Behavior, 19, pp. 50-60.

${ }^{13}$ Baker, E.S., Maw, A.S., Johnson, P.J., Macdonald, W.D. (2020). Not in My Backyard: Public Perceptions of Wildlife and 'Pest Control' in and around UK Homes, and Local Authority 'Pest Control', Animals, 10(2), p. 222.

${ }^{14}$ Lau P.L. (2019). The Legacy of Eugenics in Contemporary Law, Comparative Legal Frameworks for Pre-Implantation Embryonic Genetic Interventions, pp. 27-72.

${ }^{15}$ Gray, C., Fordyce, P., op. cit.

${ }^{16}$ Brønstad, A., Newcomer, C.E., Decelle, T., Everitt, J.I., Guillen, J., Laber, K. (2016). Current Concepts of Harm-Benefit Analysis of Animal Experiments - Report From the AALAS-FELASA Working Group on Harm-Benefit Analysis - Part 1, Laboratory Animals, 50(1S), pp. 1-20.

${ }^{17}$ Ibid.
} 


\section{Outline for Determining Best Interests for Pet Animals Using the UN Rights Convention}

Though suggesting an attitude that gives the grit of "best interests" accessible to explanation, and praising the suppleness of such a perspective, the UN Convention on the Rights of the Child has suggested more than a few considerations for presence in any "best interests" design. ${ }^{18}$

UN Convention on the Rights of the Child elements for "Best Interests" design:

- the child's point of view

- the child's individuality

- nursing, safety, and wellbeing of the child

- situation of helplessness

- the child's right to healthiness

- the child's right to schooling.

A feasible explanation for pet patients:

- a human carer could understand pets' favourites

- keeping human-pet interactions

- safeguarding wellbeing and safeguard from maltreatment

- concerns for neglected and abandoned animals

- benefits of treatment evaluated a long side risks and consequences.

All presented designs for the UN Convention on the child elements' rights for "best interests," and feasible explanation for pet patients possess their good and bad sides. According to some research, they can be measured and compared, and according to others, they actually could not. ${ }^{19}$ Giving a right to health to the pets through a "best interests" design might further push the dispute along the road for animal rights and all living and food animals. ${ }^{20}$ Undeniably, the veterinary work's "self-imposed ethical ideal of advocating and defending its patient's interests in health" even now provides the pet's patient position as a matter. ${ }^{21}$

\footnotetext{
${ }^{18}$ Eaude, T. (2018). The Role of Culture and Traditions in How Young Children's Identities are Constructed, International Journal of Children's Spirituality, 24(1), pp. 5-19.

${ }^{19}$ Krupenye, C., Kano, F., Hirata, S., Call, J., Tomasello, M. (2016). Great Apes Anticipate That Other Individuals Will Act According to False Beliefs, Science, 354(6308), pp. 110-114.

${ }^{20}$ Popović, S., Puvača, N., Peulić, T., Ikonić, P., Spasevski, N., Kostadinović, Lj., Đuragić, O. (2019). The Usefulness of Dietary Essential Oils Mixture Supplementation on Quality Aspect of Poultry Meat, Journal of Agronomy, Technology and Engineering Management, 2(6), pp. 335-343.

${ }^{21}$ Gray, C., Fordyce, P., op. cit.
} 


\section{4. "Best Interests" Design for Pets Through the Functional Attitude}

Every "best interests" design, both for kids or pets, automatically entails two fundamental aspects. The first is the medical knowledge of the healthcare professional, translated into accessible information for the nurse. ${ }^{22}$ The second one is the patient's distinctive character, inferred by the nurse as the patient's inclinations and ideals. ${ }^{23}$ From the human point of view, both of these aspects must have the same contribution to the debate surrounding "best interests," which might be accomplished by combining the principles of mutual choice-making. ${ }^{24}$

That way of the relationship among veterinary healthcare professionals and pets owners needs conversation of the economic obligations of treatment, which might influence the option which are accessible. When the pet owner could not manage to pay for the treatment which is needed, the private enterprise veterinary healthcare market dictates that the options available may include severance of the relations among the owner and pet, concerning United Kingdom. ${ }^{25}$ When the owner states that he is unable to pay for the proposed surgery and is not suitable for referral to a veterinary charitable trust for treatment, he gets several options to consider, such as:

- The veterinary clinic will operate the pet at a significantly reduced rate, or they will offer a payment fee plan that fits with the owner economic condition

- Pet owner will surrender possession of the pet to the clinic, with a deal that the pet will be relocated to another owner once the surgery has been positively carried out

- Pet owner will decide to euthanasia of his pet.

All of the given options can be evaluated in more detail with a principal focus on the "best interests" of the pet, relating these to similar provisions in the Convention on the rights of the child. ${ }^{26}$ The first option is distinctive in

\footnotetext{
${ }^{22}$ Gray, C., Fordyce, P., op. cit.

${ }^{23}$ Hughes, A., op. cit.

${ }^{24}$ Smeyers, P. (2010). Child Rearing in the "Risk" Society: On the Discourse of Rights and the "Best Interests of a Child", Educational Theory, 60(3), pp. 271-284.

${ }^{25}$ Gray, C., Fordyce, P., op. cit.

${ }^{26}$ Shaw, J.R., Lagoni, L. (2007). End-of-Life Communication in Veterinary Medicine: Delivering Bad News and Euthanasia Decision Making, Veterinary Clinics of North America: Small Animal Practice, 37(1), pp. 95-108.
} 
maintaining the current connection, which seems to be of value to the pet, thus respecting pet "views and identity." The second option would involve separating the present human-animal relationship while finding a new owner after successful surgery and recovery. While option three may thwart harm by putting an end to suffering, it would also deprive the pet of the capability to feel a "life worth living". ${ }^{27}$

Such problems can be observed over the viewpoint of contradictory normative ethical systems such as utilitarianism, deontology, virtue ethics, rights discourse, and relational and care ethics. Matters such as the good or harm a treatment might trigger and especially debates about pointless treatment can be grown inside the "beneficence/non-maleficence" tenets. Likewise, matters concerning legal and moral rights and duties and equality related to problems such as funding treatment and breaking of relationships would fall under the principle of justice. ${ }^{28}$

\section{Conclusions}

Usage of "best interests" design chosen has been highlighted in choicemaking about kids' medical treatment. In considering whether a similar design can be suitable for pets, the paper observed the doubted foundation for such design, drawing on the parameters advocated by the Convention on the Rights of the Child. Numerous problems intrinsic in such atactic, not slightest the discrepancy in legal status among kids and pets, make such a difference problematical. Furthermore, the design of best interests for pets' patients is much dependent on the human explanation of pet preferences and standards and the willingness and capability of the pet owner to pay for medical treatment.

In generating a provisional set of benchmarks while trying to design the "best interests" of a pet, some criteria have purpose fully kept accessible to interpretation. Such a strategy is consistent with the objective of the UN Convention on the Rights of the Child. An important contributing factor to the accomplishment of such an approach is the significance of excellent communication. The veterinary surgeon must communicate appropriately with the client to facilitate a "best interests" conversation.

\footnotetext{
${ }^{27}$ Fordyce, P. (2019). A Discussion of Teaching Clinical Veterinary Ethics to Undergraduates: Personal Thoughts from the Front Line, Journal of Animal Welfare Science, Ethics and Law Veterinary Association, pp. 54-61.

${ }^{28}$ Gray, C., Fordyce, P., op. cit.
} 
After all, through these efforts, the paper suggests that the pet animal patient, although currently deficient in legal subject status, merits to be deemed an ethical subject whose concerns are valuable of crucial importance by the humans engaged in creating choices on their behalf.

\section{Acknowledgments}

This research was funded by the Ministry for Education, Science and Technological Development of the Republic of Serbia under the Grant III46012/5, and supported by COST Action European Network for Optimization of Veterinary Antimicrobial Treatment under the Grant CA18217.

\section{Nikola Puvača}

Prof. dr, Fakultet za ekonomiju i inženjerski menadžment u Novom Sadu, Univerzitet Privredna akademija u Novom Sadu, Srbija

\section{Britt Chantal}

Direktor sektora za komunikacije, Švajcarrscki Centar 3RCC u Bernu, Univerzitet u Bernu, Švajcarska

\section{DOBROBIT I PRAVNI ASPEKTI U DONOŠENJU ODLUKA PRILIKOM IZBORA MEDICINSKOG TRETMANA U LEČENJU KUĆNIH LJUBIMACA}

REZIME: Kada je reč o ljudima i potrebi za lečenjem njihove dece, roditeljska odgovornost je presudna. Odluke roditelja uključuju pravne aspekte, kao i aspekte socijalne zaštite. Kućni ljubimci su obično u Evropskoj uniji klasifikovani kao vlasništvo čoveka, ali i kućni ljubimci su isti kao i deca kada je u pitanju lečenje i njihove bolesti. Kada dođe do pojave bolesti, vlasnici kućnih ljubimaca odlučuju o toku lečenja, što predstavlja pravni izazov u slučaju da predloženi tretman lečenja ima mogućnost da izazove štetu ili nepotrebnu bol, što je i definisano Zakonom o dobrobiti životinja. U ovom radu biće razmotreni najbolji interes i pravnih i 
socijalnih aspekata u odlučivanju lečenja kućnih ljubimaca od strane njihovih vlasnika. Odabir načina lečenja kućnih ljubimaca biće prvenstveno usmeren na zaštitu i dobrobit kućnih ljubimaca i zaobilaženje nepotrebnih bolova, što je u najboljem interesu kućnih ljubimaca. Iako Zakon ne nalaže uzimanje u obzir najboljih interesa kućnih ljubimaca, ovaj rad može biti koristan izvor informacija za veterinare praktičare, ali i lekare. Takođe, ovaj rad govori o najboljem interesu kućnih ljubimaca i može se integrisati u postojeće etičke okvire za donošenje medicinskih odluka i humanije postupanje sa kućnim ljubimcima u budućnosti.

Ključne reči: pravni aspekti, veterinarstvo, kućni ljubimci, dobrobit kućnih ljubimaca.

\section{References}

1. Back, A., Arnold, R., Baile, W., Tulsky, J., Fryer-Edwards, K. (2005). Approaching Difficult Communication Tasks in Oncology, A Cancer Journal for Clinicians, 55, pp. 164-177

2. Baker, E.S., Maw, A.S., Johnson, P.J., Macdonald, W.D. (2020). Not in My Backyard: Public Perceptions of Wildlife and 'Pest Control' in and around UK Homes, and Local Authority 'Pest Control', Animals, 10(2), p. 222

3. Branscombe, N.R., Schmitt, M.T., Schiffhauer, K. (2007). Racial Attitudes in Response to Thoughts of White Privilege, European Journal of Social Psychology, 37(2), pp. 203-215

4. Brønstad, A., Newcomer, C.E., Decelle, T., Everitt, J.I., Guillen, J., Laber, K. (2016). Current Concepts of Harm-Benefit Analysis of Animal Experiments - Report From the AALAS-FELASA Working Group on Harm-Benefit Analysis - Part 1, Laboratory Animals,50(1S), pp. 1-20

5. Brune, K., Renner, B., Tiegs, G. (2014). Acetaminophen/Paracetamol: A History of Errors, Failures and False Decisions, European Journal of Pain, 19(7), pp. 953-965

6. Eaude, T. (2018). The Role of Culture and Traditions in How Young Children's Identities are Constructed, International Journal of Children's Spirituality, 24(1), pp. 5-19

7. Fordyce, P. (2019). A Discussion of Teaching Clinical Veterinary Ethics to Undergraduates: Personal Thoughts from the Front Line, Journal of Animal Welfare Science, Ethics and Law Veterinary Association, pp. 54-61 
8. Glenk, L.M. (2017). Current Perspectives on Therapy Dog Welfare in Animal-Assisted Interventions, Animals, 7(2), p. 7

9. Gray, C., Fordyce, P. (2020). Legal and Ethical Aspects of 'Best Interests' Decision-Making for Medical Treatment of Companion Animals in the UK, Animals, 10(6), p. 1009

10. Hughes, A. (2017). Understanding the Drivers of Southeast Asian Biodiversity Loss, Ecosphere, 8(1), pp. 16-24

11. Krupenye, C., Kano, F., Hirata, S., Call, J., Tomasello, M. (2016). Great Apes Anticipate That Other Individuals Will Act According to False Beliefs, Science, 354(6308), pp. 110-114

12. Lau P.L. (2019). The Legacy of Eugenics in Contemporary Law, Comparative Legal Frameworks for Pre-Implantation Embryonic Genetic Interventions, pp. 27-72

13. Manning, J. (2018). "Fair, Simple, Speedy and Efficient"? Barriers to Access to Justice in the Health and Disability Commissioner's Complaints Process in New Zealand, New Zealand Law Review, 4, pp. 611-656

14. Popović, S., Puvača, N., Peulić, T., Ikonić, P., Spasevski, N., Kostadinović, Lj., Đuragić, O. (2019). The Usefulness of Dietary Essential Oils Mixture Supplementation on Quality Aspect of Poultry Meat, Journal of Agronomy, Technology and Engineering Management, 2(6), pp. 335-343

15. Puvača, N., de Llanos Frutos, R. (2020). Risk of Antimicrobial Resistance Development from Pet Animals to Humans: Case of Enterobacteriaceae Family, Lupine Online Journal of Pharmacology \& Clinical Research, 2(3), pp. 202-206

16. Ramsey, P.L., Khan, S. (2020). Dilemmas, emotion and innovation in tertiary education, Innovations in Education and Teaching International

17. Shaw, J.R., Lagoni, L. (2007). End-of-Life Communication in Veterinary Medicine: Delivering Bad News and Euthanasia Decision Making, Veterinary Clinics of North America: Small Animal Practice, 37(1), pp. 95-108

18. Smeyers, P. (2010). Child Rearing in the "Risk" Society: On the Discourse of Rights and the "Best Interests of a Child", Educational Theory, 60(3), pp. 271-284

19. Vaughan Brakman, S. (2019). The Principle of Subsidiarity in the Hague Convention on Intercountry Adoption: A Philosophical Analysis, Ethics \& International Affairs, 33(2), pp. 207-230

20. Yeates, J. (2010). Death is a Welfare Issue, Journal of Agricultural and Environmental Ethics, 23, pp. 229-241

21. Ziv, G. (2017). The Effects of Using Aversive Training Methods in Dogs-A Review, Journal of Veterinary Behavior, 19, pp. 50-60 